\title{
Do Not Dispense Refills
}

National Cancer Institute

\section{Source}

National Cancer Institute. Do Not Dispense Refills. NCI Thesaurus. Code C128511.

The dispenser must not dispense refills of the drug. 